\title{
Archaeological Testing of 41BX1788 on the Salado Creek Greenway near Voelcker Ranch, San Antonio, Bexar County, Texas
}

Leonard Kemp

Center for Archeological Research, University of Texas at San Antonio

Follow this and additional works at: https://scholarworks.sfasu.edu/ita

Part of the American Material Culture Commons, Archaeological Anthropology Commons, Environmental Studies Commons, Other American Studies Commons, Other Arts and Humanities Commons, Other History of Art, Architecture, and Archaeology Commons, and the United States History Commons

Tell us how this article helped you.

This Article is brought to you for free and open access by the Center for Regional Heritage Research at SFA ScholarWorks. It has been accepted for inclusion in Index of Texas Archaeology: Open Access Gray Literature from the Lone Star State by an authorized editor of SFA ScholarWorks. For more information, please contact cdsscholarworks@sfasu.edu. 


\section{Archaeological Testing of 41BX1788 on the Salado Creek Greenway near Voelcker Ranch, San Antonio, Bexar County, Texas}

\section{Creative Commons License}

\section{(c) (1) (8)}

This work is licensed under a Creative Commons Attribution-NonCommercial 4.0 International License 


\section{Archaeological Testing of $41 \mathrm{BX} 1788$ on the Salado Creek Greenway near Voelcker Ranch, San Antonio, Bexar County, Texas}

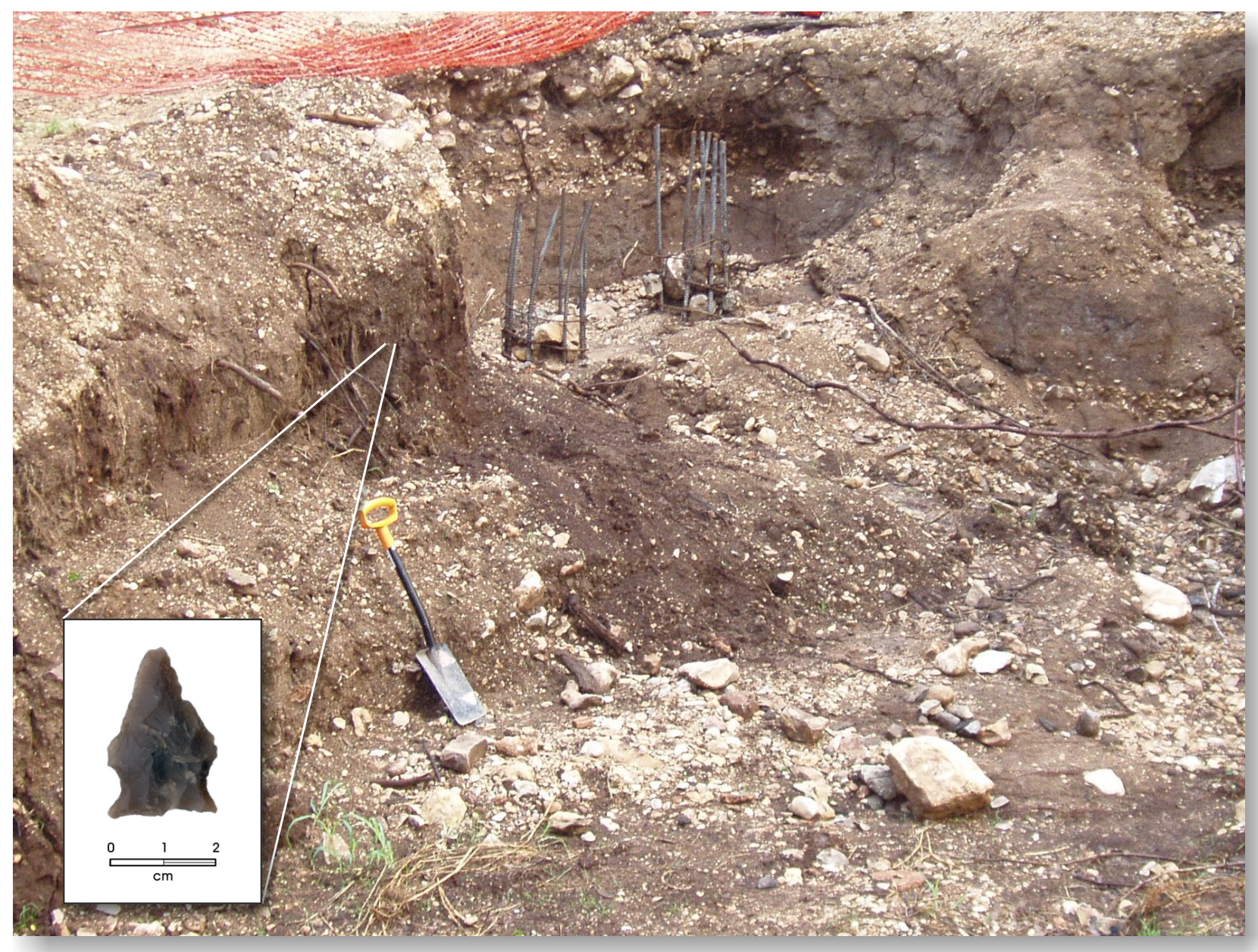

by

Leonard Kemp

Texas Antiquities Permit No. 5030

Prepared for:

Rehler, Vaughn, and Koone, Inc.

233 N. Pecos, Suite. 420

San Antonio, Texas 78207

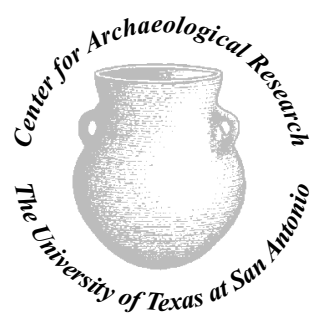

(C)2009
Prepared by:

Center for Archaeological Research The University of Texas at San Antonio Archaeological Report, No. 397 


\section{Archaeological Testing of $41 \mathrm{BX} 1788$ on the Salado Creek Greenway near Voelcker Ranch, San Antonio, Bexar County, Texas}

by

Leonard Kemp

Texas Antiquities Committee Permit No. 5030

Principal Investigator

Steve A. Tomka

Prepared for:

Rehler, Vaughn, and Koone, Inc. 233 N. Pecos, Suite. 420

San Antonio, Texas 78207

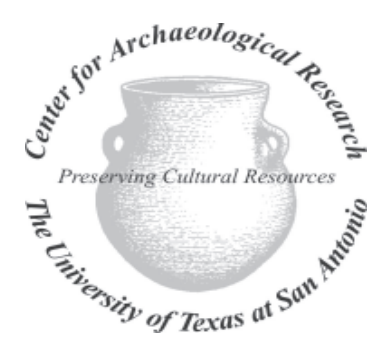

Center for Archaeological Research The University of Texas at San Antonio Archaeological Report No. 397 



\begin{abstract}
:
In September of 2008, The Center for Archaeological Research (CAR) of The University of Texas at San Antonio (UTSA) conducted eligibility testing of a previously unknown archaeological site adjacent to the Salado Creek Greenway near the Voelcker Ranch, located in San Antonio, Bexar County, Texas. 41BX1788 was found by a local resident after the construction of piers for a pedestrian bridge associated with the Salado Creek Greenway. The primary purpose of testing was to determine if any intact cultural deposits or features remained that would be impacted by further bridge construction. CAR excavated a $1 \mathrm{x}$ 1-meter test unit and found no features or intact deposits that merit further investigation. Due to the mixing of modern materials with prehistoric deposits caused by multiple processes, CAR suggests that the archaeological deposits have low research value and the site does not warrant nomination to the National Register of Historic Places or designation as a State Archaeological Landmark. We recommend that bridge construction proceed as planned.
\end{abstract}

The archaeological investigations were conducted under Texas Antiquities Permit \# 5030 with Steve A. Tomka as Principal Investigator. All collected artifacts and project associated documents are permanently curated at the Center for Archaeological Research. 


\section{Table of Contents:}

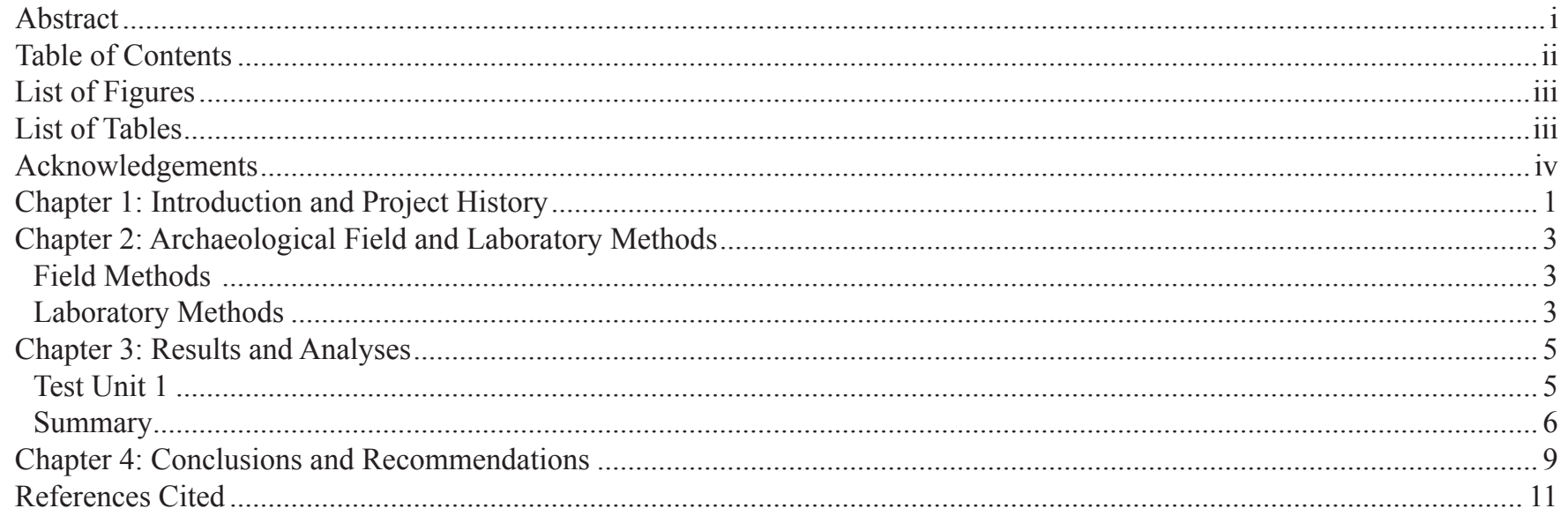




\section{List of Figures:}

Figure 1-1. Map showing location of 41BX1788.

Figure 1-2. Portion of terrace deposits containing cultural materials (top). Carbonized wood, bone, and chipped lithic tools, including a possible Darl point, collected from project area (bottom)........................................ 2

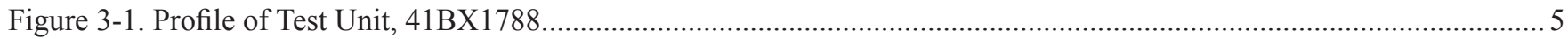

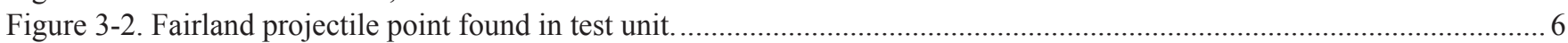

Figure 3-3. Fire-cracked rock embedded immediately below road base (top). Image (bottom) shows the path of the sanitary line in relation to the location of the test unit

\section{List of Tables:}

Table 3-1. Cultural Material Recovered from Test Unit (41BX1788) 


\section{Acknowledgements:}

The completion of this project could not have occurred without the support of several individuals. The author would like to thank the field crew from the Center for Archaeological Research (CAR), Nathan Devito and Linda Martinez. A thanks to Mark Denton of the Texas Historical Commission, and Kay Hindes of the City of San Antonio Historic Preservation Division for visiting the site and providing comments. Larry Hicks of Rehler, Vaughn, and Koone, Inc. (RVK) facilitated requests from CAR which helped in the completion of this work. Thanks to Johnny Vandermullen of Dutch Construction Company for operating the backhoe during field work. Steve A. Tomka served as the Principal Investigator and provided comments on the draft report, as well as providing guidance during the project. Bruce Moses served as Technical Editor for the final version of this report. And finally thanks to Robert Walker, who found the site and reported his findings to the contractor/ designer, RVK, Inc, the City of San Antonio, and CAR. Mr. Walker visited the site during the field work and shared his interest in the archaeology of the area as well as reporting on the recent evolution of the landforms surrounding the site. 


\section{Chapter 1: Introduction and Project History}

The Center for Archaeological Research (CAR) of The University of Texas at San Antonio (UTSA) was contracted by Rehler, Vaughn, and Koone, Inc. (RVK) to conduct Phase II archaeological testing of a previously unknown archaeological site (subsequently designated as 41BX1788), on the Salado Creek Greenbelt Project in San Antonio, Texas. Figure 1-1 shows the site in relation to the test unit, and the present and previous construction.
On August 26, 2008, Steve A. Tomka, Director of CAR was notified by RVK that prehistoric archaeological materials were found eroding from the banks of an unnamed tributary associated with construction of a bridge for the Salado Creek Greenway. These artifacts were found by a local resident, a member of the Southern Texas Archaeological Association. Images forwarded by RVK, Inc. from this individual showed debitage and burned rock in dark stained deposits suggesting

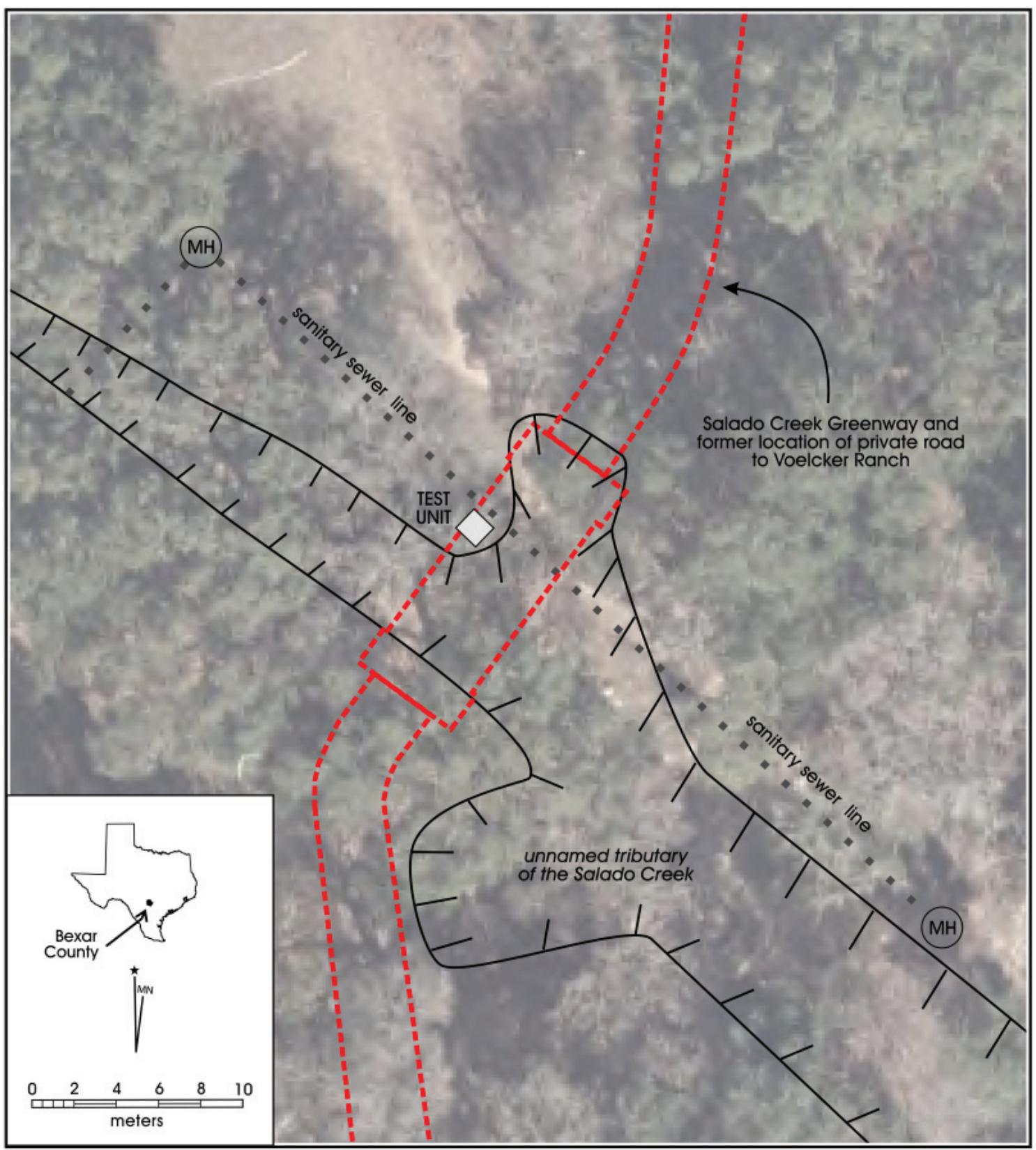

Figure 1-1. Map showing location of $41 B X 1788$. 
an organically enriched stratum in a terrace wall (see Figure1-2). Other images showed lithic tools, including a possible Darl projectile point, biface fragments, fire cracked rock and faunal bone collected by this individual (see Figure 1-2). A visit to the site by Tomka, Kay Hindes, the City of San Antonio's historic preservation officer, Brandon Ross of the Parks and Recreation Department, and Larry Hicks of RVK, Inc. occurred the following day. An inspection of the site noted debitage, fire cracked rock and charcoal staining below the remnants of an existing asphalt road leading to Voelcker Ranch. This area was substantially impacted by this, as well as previous construction. While noting that these cultural materials appeared to be disturbed by the construction, it was determined that further investigation was warranted to determine if any intact deposits remained before any further construction could proceed.

While the Center had conducted pedestrian survey along this portion of Salado Creek (Figueroa and Ulrich 2006), the Voelcker Ranch property was not surveyed because no Right-of-Entry (ROE) was available at the time of the investigations. The CAR technical report identified this area as not surveyed and needing survey following acquisition.

The fact that the proposed work would take place on land owned by Bexar County, a political subdivision of the state, brings the project under the jurisdiction of the Antiquities Code of Texas. Also, because the project occurs within the limits of the City of San Antonio, the project falls under the jurisdiction of the City of San Antonio Unified Development Code, Chapter 35. The principal oversight agency is the Archeology Division of the Texas Historical Commission (THC). Archaeological investigations were conducted under THC Permit No. 5030.

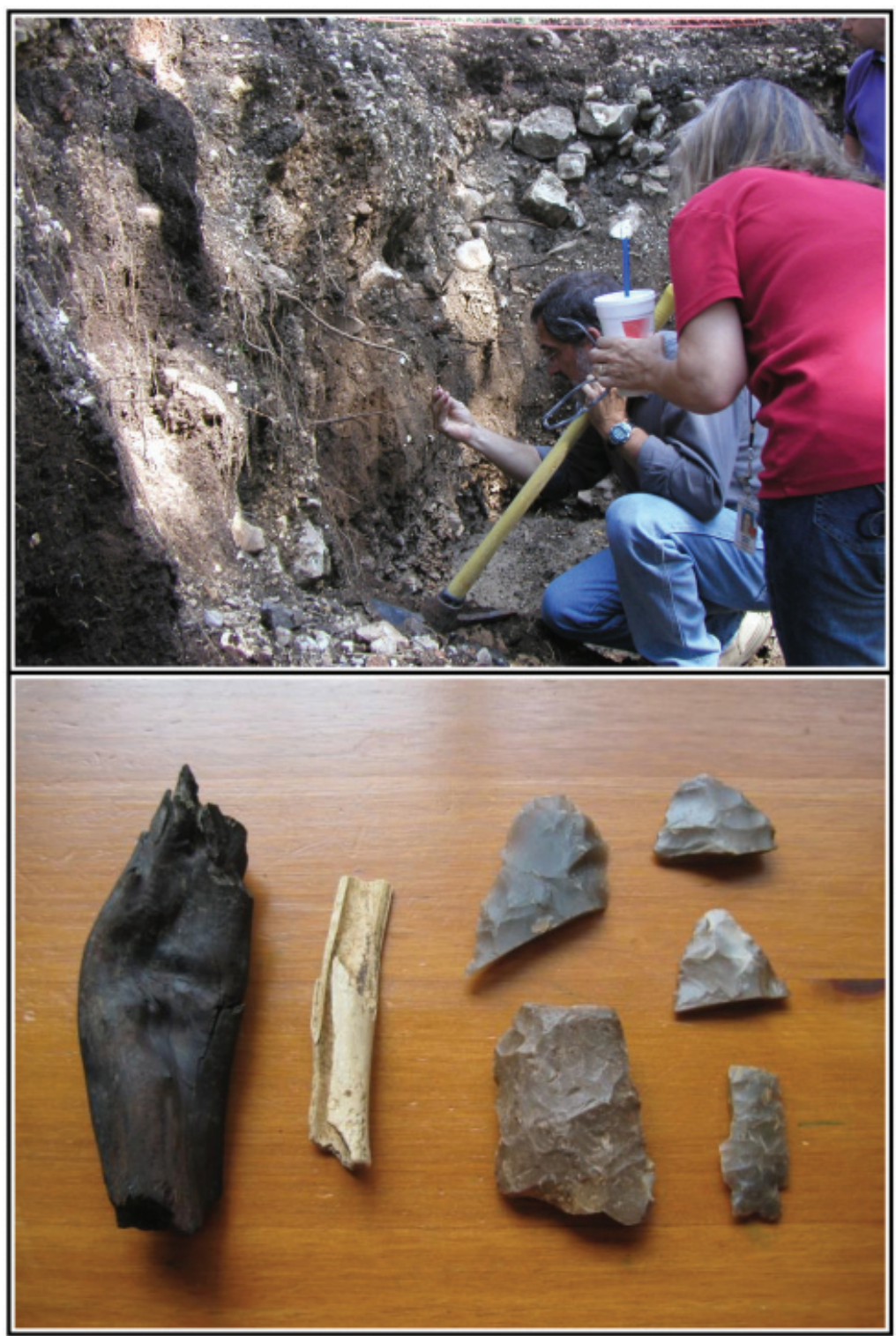

Figure 1-2. Portion of terrace deposits containing cultural materials (top). Carbonized wood, bone, and chipped lithic tools, including a possible Darl point, collected from project area (bottom). 


\section{Chapter 2: Archaeological Field and Laboratory Methods}

In concurrence with the Texas Historical Commission (THC), CAR developed a testing strategy to determine the eligibility of 41BX1788 for inclusion in the National Register of Historic Places, and formal designation as a State Archaeological Landmark as well as to assess its potential to answer archaeological questions. The following describes excavation strategies and decisions undertaken in the field during testing. It also describes laboratory methods and the curation of materials and documents generated during this project.

\section{Field Methods}

Archaeological testing occurred over a three day period from September 8-10, 2008. The Phase II testing consisted of the excavation of a single $1 \times 1$ meter test unit within the area where cultural materials were eroding from what appeared to be an organically stained stratum. As noted in Chapter 1, a significant portion of 41BX1788 is believed to have been destroyed either during the construction of the private roadway, sanitary line construction and/or the present construction of the bridge piers. The investigation focused on an area of approximately 5 by 6 meters that appeared to be relatively undisturbed beneath the roadway and containing cultural material. The excavation of the test unit is estimated to have examined approximately $3.3 \%$ of the approximately $30 \mathrm{~m} 2$ remaining of the site. No features were found during the excavation.

To facilitate this excavation approximately $20 \mathrm{~cm}$ of overburden, consisting of asphalt and road base, was removed prior to excavation. As the unit was positioned to excavate from the side wall of the terrace, we also screened a bulk (approximately $.20 \mathrm{~m} \times 1 \mathrm{~m} \times 1 \mathrm{~m}$ ) in concert with the test unit levels. All cultural material found in the bulk, the face of the terrace, was discarded with the exception of temporal diagnostics or tools. The unit was excavated in $10-\mathrm{cm}$ levels by hand with the matrix from these levels screened through $1 / 4$ " hardware cloth. All cultural material found was collected and bagged by level with descriptive level form filled out for each level. This form included the type and a field count of artifacts found, as well as the composition, color and relative hardness of the soil in which these artifacts were found. The unit was photographed prior to and upon completion of excavation. Both north and west walls of the test unit were profiled with notations of soil color, and type. The location of the unit was recorded on a Trimble GeoXT, as was the location of a nearby sewer line and the present trail (Figure 1-1).

\section{Laboratory Methods}

All archaeological materials recovered during the project were fully analyzed, described, and reported. All cultural materials and records obtained and/or generated during the project were prepared in accordance with federal regulation 36 CFR part 79, and THC requirements for State Held-in-Trust collections. Artifacts processed in the CAR laboratory were washed, airdried, and stored in 4-mm zip locking archival-quality bags. Organic materials and materials needing extra support were double-bagged. Acid-free labels were placed in all artifact bags. Each label contained provenience information and a corresponding lot number written in archival ink, with pencil or laser printed. Ceramics were labeled with the appropriate provenience data. Artifacts were separated by class and stored in acid free boxes. Digital photographs were printed on acid free paper and labeled with archivally appropriate materials and placed in archival-quality sleeves along with a $C D$ containing the digital files. All field forms were completed in pencil.

In consultation with THC, subsequent to proper analyses and/or quantification, artifacts possessing little scientific value were discarded pursuant to Chapter $26.27(\mathrm{~g})(2)$ of the Antiquities Code of Texas. Artifact classes discarded specific to this project included: burned rock, snail shell, unidentifiable metal, soil samples, and recent (post-1950) materials. In all instances, however, discarded materials were documented and their counts included in the final report and curation documentation. 



\section{Chapter 3: Results and Analyses}

This chapter presents the results and assesses the eligibility of 41BX1788 for NHRP nomination.

\section{Test Unit 1}

After removal of overburden, Test Unit 1 (TU1) was excavated in 10-cm levels to a depth of $100 \mathrm{~cm}$ below the datum. Figure 3-1 shows the stratigraphy of the west and north walls. The west wall can be divided into four zones. The north wall has an additional and distinct zone associated with the construction of the sanitary line. Zone 1 is the remnant of the road base and is composed of pea-sized gravels and cemented sand approximately $10-\mathrm{cm}$ in depth. The transition to Zone 2 is abrupt characterized by a brown silty clay matrix with large and frequent limestone cobbles. Zone 3 is composed of similar sediments with a dramatic reduction of both the frequency and size of limestone cobbles. Zone 4 is composed of approximately 75 to $80 \%$ alluvial gravels that begin approximately $95 \mathrm{~cm}$ below the datum. Zone 5 is a distinct, very soft silty loam with very fine roots comprising approximately 30 to $40 \%$ of the eastern portion of the unit.

Salado Creek can be divided into an Upper, Middle and Lower Salado based upon gradient and channel definition (Potter et al. 1995:8). These characteristics affect the potential of finding intact, and for our purposes archaeological sites that are eligible for NHRP nomination, in the immediate vicinity of the creek channel. 41BX1788 is located in an area termed by Potter et al. (1995) as the Upper Salado Creek. It is characterized by steep gradient and narrow floodplains which drain the Balcones Escarpment sub-region of the Edwards Plateau (Potter et al. 1995:9). The uplands consist of relatively shallow soils over weathered bedrock that tend to be either stable or deflating (Potter et al. 1995:10). Moderate to heavy rains produce high

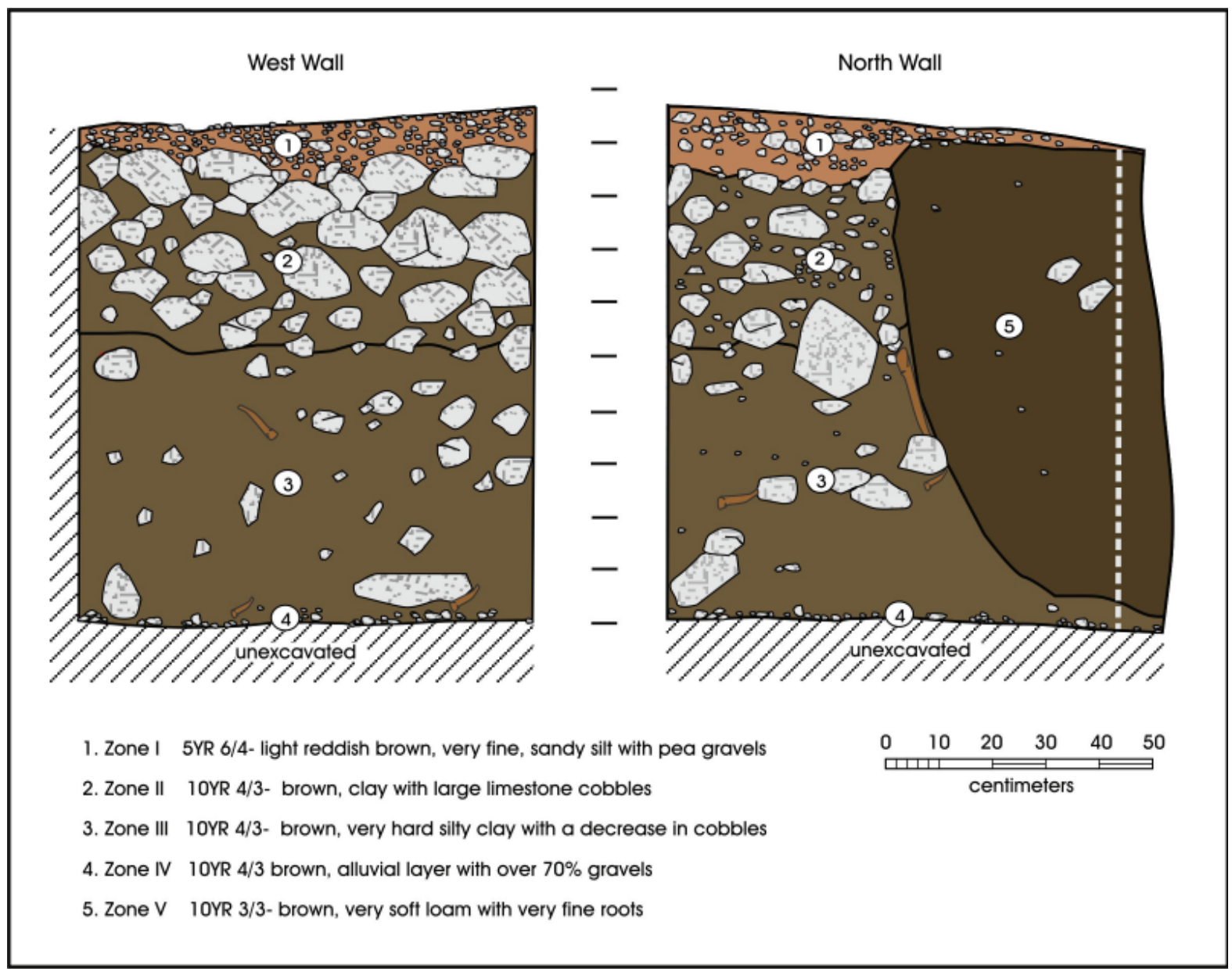

Figure 3-1. Profile of Test Unit, 41BX1788. 
velocitywaterdischargecapable of transporting cobbles and gravels (Potter et al. 1995:8). The west wall profile appears to typify this depositional regime characterized by the mixing of cobbles, pebbles, and surface artifacts.

Both prehistoric and modern artifacts were found through out the test unit. Table 3-1 gives the types and counts of artifacts found by level. As noted in Chapter 1, a projectile point identified as a Darl was found by a local resident in the vicinity of the test unit. During excavation, another projectile point was recovered $40 \mathrm{~cm}$ below the datum and identified as Fairland (Figure 3-2). Both artifacts suggest that the deposit has a Late Archaic affiliation. Fire-cracked rocks ranging in size from $5 \mathrm{~cm}$ to $15 \mathrm{~cm}$ in diameter were recovered in all levels. Modern materials were found in all but three of the levels with Level 9, second to the deepest level, having glass, metal, and asphalt. The occurrence of modern materials throughout the unit, as well as the depth of this intrusion, would suggest that vertical mixing has occurred.

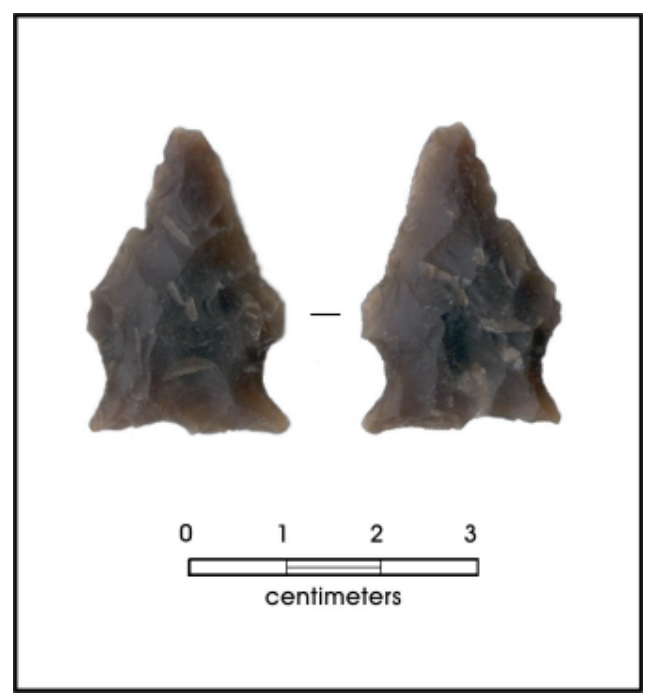

Figure 3-2. Fairland projectile point found in test unit.
Table 3-1. Cultural Material Recovered from Test Unit (41BX1788)

\begin{tabular}{|c|c|c|c|c|c|c|c|c|c|}
\hline Level & $\begin{array}{c}\text { Depth (cm } \\
\text { below } \\
\text { datum) }\end{array}$ & Debitage & $\begin{array}{c}\text { Lithic } \\
\text { Tools }\end{array}$ & $\begin{array}{c}\text { Burned } \\
\text { Rock }\end{array}$ & $\begin{array}{c}\text { Road } \\
\text { Material }\end{array}$ & Metal & Glass & Snail & Charcoal \\
\hline $1 \& 2$ & $0-20$ & 7 & 0 & Present & 1 & 0 & 0 & - & - \\
\hline 3 & $20-30$ & 4 & 1 & Present & 0 & 0 & 0 & - & - \\
\hline 4 & $30-40$ & 8 & 1 & Present & 1 & 1 & 0 & - & - \\
\hline 5 & $40-50$ & 24 & 0 & Present & 0 & 1 & 0 & Present & Present \\
\hline 6 & $50-60$ & 17 & 0 & Present & 0 & 0 & 0 & Present & - \\
\hline 7 & $60-70$ & 7 & 0 & Present & 0 & 0 & 0 & Present & - \\
\hline 8 & $70-80$ & 10 & 1 & Present & 1 & 0 & 0 & Present & - \\
\hline 9 & $80-90$ & 18 & 0 & Present & 1 & 1 & 1 & Present & - \\
\hline 10 & $90-100$ & 5 & 0 & Present & 0 & 0 & 0 & Present & - \\
\hline Total & & 100 & 3 & & 4 & 3 & 1 & & \\
\hline
\end{tabular}

Both the west and north walls show the impact of previous construction upon the site. An examination of the profile (Figure 3-3 top) created by the present construction shows that the immediately surrounding gravels and cobbles were used to build a base for the road. The material used as road base also contained fire-cracked rock and debitage. Sometime in the past, the San Antonio Water System placed a sanitary line through 41BX1788. The pipeline was cut through the bedrock and is immediately north of the test unit. Figure 3-3 (bottom) shows the orientation of the sanitary line relative to the location of Test Unit 1 . While the degree of destruction cannot be assessed in any quantitative fashion, these disturbances have substantially impacted the integrity of the deposits present at 41BX1788.

\section{Summary}

41BX1788 is a Late Archaic site that contained lithic tools, debitage, and fire-cracked rock. The site's deposits were found after the construction of a bridge for the Salado Greenway project. In order to assess the NHRP eligibility of the site, a test unit was placed within the highest concentration of visible artifacts. Based upon landform and artifact analyses, it appears that archaeological deposits are no longer intact, with mixing of prehistoric and modern materials to approximately $90 \mathrm{~cm}$ below the test unit datum. Based upon the lack of integrity, we conclude that the deposits have low research potential, and we recommend that 41BX1788 is ineligible for nomination to the NHRP. 

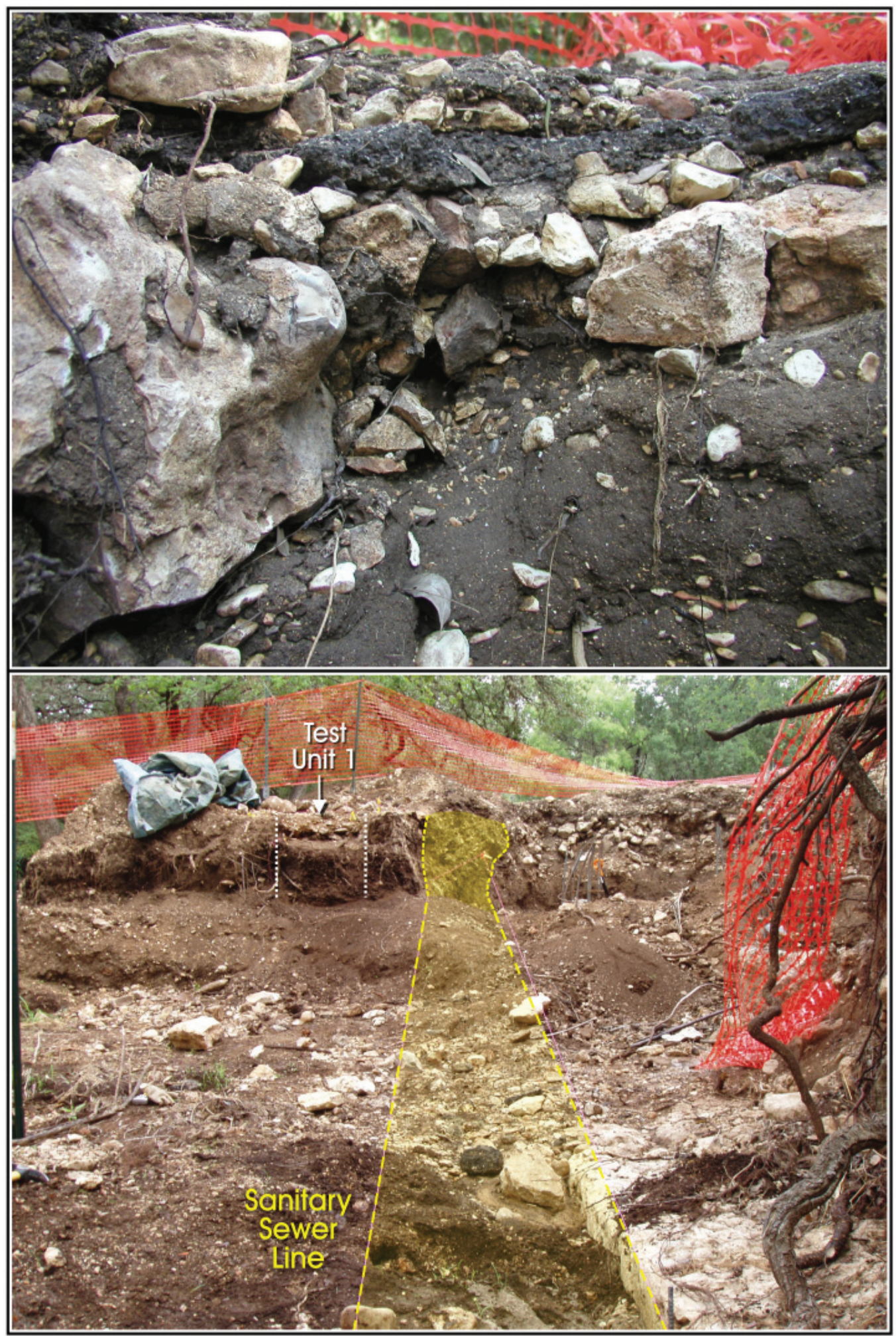

Figure 3-3. Fire-cracked rock embedded immediately below road base (top). Image (bottom) shows the path of the sanitary line in relation to the location of the test unit. 



\section{Chapter 4: Conclusions and Recommendations}

The investigation of $41 \mathrm{BX} 1788$ consisted of a $1 \times 1$-meter test unit excavated to a depth of $100 \mathrm{~cm}$ below the datum. The test unit was placed on a terrace of an unnamed tributary of the Salado Creek and focused on an area approximately 5 x 6 meters that contained what appeared to be an organically enriched deposit with eroding prehistoric cultural materials. The construction of the pedestrian bridge, as well as previous construction, has significantly impacted the integrity of any remaining cultural deposits. Based upon temporal diagnostics, the deposits appear to have a Late Archaic temporal affiliation with a significant amount of debitage and fire-cracked rock. In addition, modern materials were found in the unit to a depth of $90 \mathrm{cmbd}$. Analyses of artifacts and stratigraphy of Test Unit 1 suggest that both modern and prehistoric artifacts are intermixed to a depth of approximately 1 to $1.5 \mathrm{~m}$ below the existing surface. CAR suggests that these archaeological deposits have low research value and 41BX1788 does not warrant nomination to the National Register of Historic Places and/or formal designation as a State Archaeological Landmark. We recommend that bridge construction proceed as planned. On September 11, 2008, Mark Denton of the Texas Historical Commission concurred with an initial assessment of 41BX1788 and permitted the resumption of bridge construction. 



\section{References Cited}

Figueroa, A.L. and K.M. Ulrich

2006 Archaeological Survey of the North Salado Greenway Belt, San Antonio, Bexar County, Texas. Archaeological Report, No. 367, The Center for Archaeological Research, The University of Texas at San Antonio.

Potter, D.R., S.L. Black and D.L. Richmond

1995 Archaeological along the Wurzbach Parkway, Module 1: Introduction, Conceptual Framework and Contexts of Archaeological Investigations in Bexar County, South-Central Texas. Studies in Archaeology 1, Texas Archaeological Research Laboratory, The University of Texas at Austin. 
